\title{
Plural addressee marker and grammaticalization in Barayin
}

\author{
Joseph Lovestrand, University of Oxford
}

\begin{abstract}
This article describes two distinct but related grammaticalization paths in Barayin, an East Chadic language. One path is from a first-person plural pronoun to a first-person dual pronoun. Synchronically, the pronominal forms in Barayin with first-person dual number must now be combined with a plural addressee enclitic, $n a$, to create a first-person plural pronoun. This path is identical to what has been documented in Philippine-type languages. The other path is from a first-person dative suffix to a suffix dedicated to first-person hortative. This path of grammaticalization has not been discussed in the literature. It occurred in several related languages, and each in case results in a hortative form with a dual subject. Hortative forms with a plural subject are created by adding a plural addressee marker to the dual form. The plural addressee marker in Chadic languages is derived from a second-person pronominal.
\end{abstract}

\section{Keywords}

Chadic, Barayin, hortative, dual, pronouns, diachronic ${ }^{1}$

\section{Introduction}

This paper describes two distinct but related grammaticalization paths in Barayin [bva] and other languages of the Guera subbranch of East Chadic languages (East Chadic B). Barayin is spoken by about 5,000 people in the Guera region of Chad. It has four dialects (Lovestrand 2011). This article is focused on the Jalkiya dialect. Some of the data used here are from an initial grammatical sketch of this dialect including a few transcribed texts (Lovestrand 2012b). Other Barayin data are from unpublished transcribed recordings from fieldwork in 2015 and 2017. 2015 data are labeled by a one-word reference to the title of the recording followed by the line number. 2017 data are labeled according to the file name of the recording, followed by the line number. These data will be made available via the website of the Endangered Language Archive (ELAR). ${ }^{2}$

The Guera subbranch (East Chadic B) is an underdocumented group of about twenty Chadic languages. Some very basic linguistic analysis has been done on sixteen of the Chadic languages of the Guera, but a preliminary analysis of the verbal morphology and pronominal paradigms are available for only thirteen

\footnotetext{
${ }^{1}$ Much of the content of this article was presented in two parts at the 2nd and 3rd Linguistics Research Student Conference at SOAS. Thanks to the participants for their feedback. Thanks to Mary Dalrymple, Carsten Peust, Stephen Jones and John Lowe for feedback on earlier drafts of this paper. Thanks to two anonymous BJALL reviewers for their constructive criticism of the final version.

${ }^{2}$ Financial support for 2015 fieldwork was provided by the Hansell Fund at Somerville College and by the Faculty of Linguistics, Philology and Phonetics (University of Oxford). Financial support for 2017 fieldwork was provided by the Endangered Languages Documentation Programme (ELDP SG0431).
} 
of these languages. The Guera region of Chad is also home to a number of Nilo-Saharan and Adamawan (Niger-Congo) languages. The language of wider communication is Chadian Arabic. ${ }^{3}$

The two grammaticalization paths presented in this article have created first-person dual inclusive morphemes that combine with a plural addressee marker nà to create a first-person plural inclusive meaning. In one path, the former first-person plural inclusive pronoun shifted to dual meaning, and the addition of the plural addressee marker is used to maintain the plural meaning. This path of grammaticalization is well-attested in other parts of the world, particularly in the Philippines. One dialect of Barayin has not undergone this change, leaving very clear evidence of the relatively recent change in the other three dialects.

In the other path, a first-person plural dative suffix (often called Indirect Object by Chadicists) grammaticalized into a suffix dedicated to first-person hortative meaning. This previously undocumented path of grammaticalization is attested in six languages of the Guera subbranch. In each of these languages, the hortative suffix on its own is understood to have a first-person dual inclusive subject. In most cases, this is the only grammaticalized dual number in the language. A first-person plural inclusive hortative form is created by adding a plural addressee marker to the dual form.

Before presenting the diachronic analysis, a synchronic analysis of of the plural addressee marker and othe relevant portions of Barayin grammar is presented in section 2 with some comparison to other Chadic languages. The first grammaticalization path, from first-person plural pronoun to first-person dual pronoun, is presented in section 3. The other grammaticalization path, from dative to hortative, is presented in section 4. The evidence of this path comes from Barayin and five other languages. Section 5 is a brief conclusion.

\section{Plural addressee marker}

This section contains a description of the plural addressee marker $n \grave{a}$ in Barayin with reference to a similar marker in related languages. The plural addressee marker is used in directive forms (Subjunctive/imperative and Horatative) (section 2.1), and in the pronominal system to distinguish first-person plural inclusive pronouns from first-person dual inclusive pronouns (section 2.2). The plural addressee marker appears to have been derived diachronically from a second-person plural pronoun.

\subsection{Directive forms (Subjunctive/imperative and Hortative )}

The plural addressee marker is used in two types of directive forms, here called Subjunctive and Hortative. I use directive as an umbrella term grouping together imperative, subjunctive, hortative and similar meanings. Mauri and Sansò (2011:3491) define the term “directive" as referring to situations in which

"the speaker wishes a state of affairs (henceforth SoA) to become true and conveys an appeal to the addressee(s) to help make this SoA true. The performer(s) of the action(s) required to bring about the desired SoA may coincide (i) with the addressee, (ii) with the speaker, (iii) with a third party or (iv) with any possible combination of (i)-(iii)."

It is common in Chadic languages for a single verbal form to be used for several of these directive situations including second-person imperatives (performer is the addressee). Frajzyngier (1996:15) describes

\footnotetext{
${ }^{3}$ All data presented are Barayin unless otherwise indicated. Glossing conventions follow the Leipzig Glossing Rules. Abbreviations used are: DAT 'dative/Indirect Object', DEM 'demonstrative', DU 'dual', EXCL 'exclusive', F 'feminine', FOC 'focus/contrastive', HORT 'hortative', IDEO ‘ideophone', IPFV ‘imperfective', INCL ‘inclusive', INF 'infinitive', M 'masculine', NEG 'negative', NMLZ 'nominalizer', OBJ 'direct object, OBL 'oblique', POSS 'possessive', PFV 'perfective', PL 'plural', PROG 'progressive', PURP 'purposive', QUOT 'quotative', REL 'relative clause marker', SBJ 'subject', SBJV 'subjunctive', sG 'singular', 1 'first-person', 2 'second-person' and 3 'third-person'. Transcriptions are given in an orthographic form without exhaustive tone marking. The graphemes represent the same segments as their IPA counterparts, with three exceptions: $<\mathrm{y}>$ for the approximate $[\mathrm{j}],<\mathrm{j}>$ for the palatal stop [f], and $<\mathrm{n}>$ for the palatal nasal [n]. See appendix 6 in Lovestrand (2012b) for more on Barayin orthography.
} 
this as the "mood of obligation with respect to the subject, in Chadic literature referred to as subjunctive." Wolff (1982a) uses the term "imperative-jussive modal category". Aikhenvald (2010:5) explains that: “"jussive' and 'injunctive' often refer to commands directed at a third-person. But in the Semitologist tradition, 'jussive' covers all non-second-person imperative marking." I will refer to this directive form as Subjunctive with a capitalized first letter. In addition to the Subjunctive form, at least six languages of the Guera subbranch also have a Hortative form dedicated to first-person directive meaning. The imperative use of the Subjunctive form is presented in section 2.1.1, and its non-imperative uses in section 2.1.2. Section 2.1.3 presents the Hortative form. Each of the languages that have a Hortative form use a plural addressee marker in both imperative (Subjunctive) and hortative contexts to distinguish between plural and non-plural subjects.

\subsubsection{Singular and plural imperative (Subjunctive)}

The Barayin examples 1, 2 and 3 are of the singular imperative use of the Subjunctive. In this use, there is no overt subject, and the verb is not in a subordinate clause. The understood subject is second-person.

(1) dow-u lafiya

sleep-SBJv health

Sleep well! (SBJ.2SG) (Lovestrand 2012b:109)

(2) kol-u

go-SBJV

Go away! (SBJ.2SG) (bva091.240)

(3) kol-u alli ana i-ju

go-SBJV there for mother-POSs.1sG

Go to my mother's house. (SBJ.2SG) (bva082.21)

In Barayin, the plural imperative is formed by the addition of the plural addressee marker $n a$ to the end of the verb, as seen in examples 4 and 5.

(4) kol=nà lapiya

go-[SBJv]=NÀ well

Have a good trip! (SBJ.2PL) (bva034.77)

(5) 1-aa=nà nopuno-ya

send-SBJV=NÀ goat-PL

Send the goats! (bva039.43)

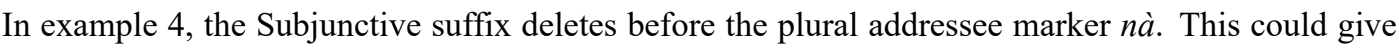
the impression that $n a \dot{a}$ is another verbal suffix in complementary distribution with the suffix $-u$ in the imperative construction. There are several reasons for analyzing $n a ̀$ as an enclitic that deletes the Subjunctive suffix. First, in a minor morphological class of verbs whose root consists of a single consonant, the Subjunctive suffix co-occurs with $n a ̀$ (example 5). The second reason for analyzing $n a ̀$ in the plural imperative construction as a clitic and not a suffix, is that it occurs following a Direct Object suffix, as seen in examples 6 and 7. There are no tense-aspect-mood (TAM) suffixes in Barayin that occur after a Direct Object suffix. TAM suffixes in Barayin undergo suppletion or deletion when the verb takes a Direct Object suffix. If $n a ̀$ in the imperative construction were a suffix in complementary distribution with $-u$, it would be expected to occur before the Direct Object suffix, not after. (6) epi-ga=nà
catch-OBJ.3sG.M=NÀ hyena

Catch the hyena! (SBJ.2PL) (bva086.108) 
(7) ep-ti=nà $\quad$ boore
catch-OBJ.3SG.F=NÀ antelope

Catch the antelope! (SBJ.2PL) (bva086.51)

The Subjunctive suffix can also be deleted by other clitics besides nà. As in most Chadic languages, the marker of negation $d o$ always occurs in clause-final position. In a clause with no post-verbal modifiers, the negation marker can occur immediately after the verb. Like all monomoraic words in Barayin, the negation marker has a tendency to phonologically attach to another word. When it does this following a verb with a Subjunctive suffix, it can delete the Subjunctive suffix, as in example 8. In other words, the Subjunctive suffix can delete before other clitics. Another verbal suffix, the Perfective suffix, also deletes when followed directly by the enclitic nà (Lovestrand 2012b:66).

(8) ka japp-a y kol=do / kol-u do

SBJ.3SG.M want-PFV SBJ.1SG go-[SBJV]=NEG / go-SBJV NEG

He doesn't want me to leave. (Lovestrand 2012b:67)

In conclusion, the plural imperative construction in Barayin is distinguished from the singular imperative construction by the presence of the plural addressee enclitic nà.

\subsubsection{Non-imperative uses of Subjunctive}

The Subjunctive form of the verb can also be used with an overt subject. This is a non-imperative use of the Subjunctive form where the performer is not necessarily the addressee. The Subjunctive with an overt subject as the main verb of an independent clause communicates a more general sense of obligation on the subject. In this use there is no restriction on the person, number or clusivity of the subject.

(9) ane kol-u duw-ga jeedo ge luwa ka gi SBJ.1PL.EXCL go-SBJV see-OBJ.3SG.M mountain REL.SG.M up SBJ.3SG.M DEM.SG.M "We should go see that mountain up there." (History 6)

(10) mijjo gi teyi joo kol-u koygulo do person DEM.SG.M like.this FOC go-SBJV IDEO NEG

Nobody should go astray. (bva022.65)

(11) nandanga doo noom-u in aka do children FOC play-SBJV with fire NEG

Children shouldn't play with fire. (Lovestrand 2012b:186)

The Subjunctive form can also occur in some finite dependent clauses, for example, complements of the verb 'want'. In this case, the matrix verb requires a Subjunctive form in its finite sentential complement. Again, there is a directive meaning, although it is not an imperative construction.

(12) ni japp-a buk-i-jiga joo wut-u do SBJ.3PL want-PFV speak-INF-POSS.3PL FOC be.lost-SBJV NEG They don't want to lose their language (bva057.60)

(13) ki japp-a ane kol-u SBJ.2SG.M want-PFV 1PL.EXCL go-SBJV

You want us to leave. (Lovestrand 2012b:111) 
Note that in examples 9, 11 and 13, the enclitic nà does not occur even though the subject of the Subjunctive clause is plural. The enclitic nà cannot co-occur with a third-person subject or first-person plural exclusive subject. This indicates that nà is not simply a plural subject agreement marker. It is only used when the addressee is plural (i.e., second-person plural and first-person plural inclusive).

In the non-imperative use of the Subjunctive, the plural addressee marker can optionally co-occur with a second-person plural subject. This is shown in example 14. In other TAM forms of the verb, the enclitic nà never co-occurs with a second-person plural subject.

$$
\begin{array}{ll}
\text { a. } & \text { ka japp-a ní gan-u kita } \\
\text { SBJ.3sG.M want-PFV SBJ.2PL make-SBJV work } & \\
\text { He wants you all to work. } & \\
\text { b. } & \text { ka japp-a ní gan=nà } \quad \text { kita } \\
\text { SBJ.3SG.m want-PFV SBJ.2PL make-[SBJV]=NÀ work } \\
\text { He wants you all to work. (Lovestrand 2012b:161) }
\end{array}
$$

The enclitic $n a ̀$ is obligatory when the subject is first-person plural inclusive. This is true in the nonimperative use of the Subjunctive, as it is with all other TAM forms of the verb. This use of the plural addressee marker is further discussed in sections 2.2 and 3.

$$
\begin{aligned}
& \text { (15) } \mathrm{y} \text { japp-a in gan=nà kita } \\
& \text { SBJ.1SG want-PFV SBJ.1DU.INCL make-[SBJV]=NÀ work } \\
& \text { I want us all to work. (SBJ.1PL.INCL) (Lovestrand 2012b:161) }
\end{aligned}
$$

In summary, in the imperative use of the Subjunctive form, the plural addressee marker nà is obligatory when the subject is second-person plural. In the non-imperative use of the Subjunctive form, the plural addressee marker is optional with a second-person plural subject, and required with a first-person plural inclusive subject. In non-Subjunctive forms of the verb, the plural addressee marker only occurs when the subject is first-person plural inclusive. It never co-occurs with a second-person plural subject if the verb is non-Subjunctive.

\subsubsection{Hortative}

Many Chadic languages have another directive form in addition to the Subjunctive form which is used exclusively with first-person subjects. I refer to this form as the hortative form. "“Hortative' (also called 'exhortative' and 'adhortative') is a frequent label for first-person imperative" (Aikhenvald 2010:4). At least sevent languages of the Guera subbranch have a hortative form: Barayin, Bidiya, Dangla, Migaama, Mogum, Saba and Sokoro. Hortative forms are also scattered throughout West and Central Chadic languages such as: Buwal (Viljoen 2013:471), Hdi (Frajzyngier 2002:274), Miya (Schuh 1998:122) and Lamang (Wolff 1983:175). The hortative in Barayin is formed by the suffix $-y a$.

(16) suli-ya $y$ kida sit-HORT OBL ground Let's (you and me) sit down. (bva052.98)

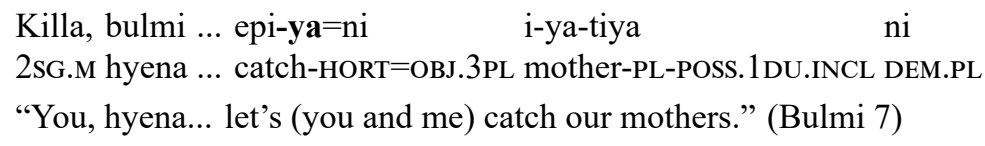

The Hortative suffix overlaps in function with the Subjunctive in that it encodes directive meaning. Like the imperative use of the Subjunctive, the Hortative is normally used without any overt subject. The unstated subject of the Hortative is understood to be limited to first-person (dual or plural) inclusive 
referents. The existence of the Hortative form does not replace the use of the Subjunctive form with firstperson plural subjects, as is seen in examples 9, 13 and 15 above. Both forms have directive meaning. A Hortative form implies a self-motivated act, whereas the Subjunctive form is unspecific as to the source of obligation on the subject.

In Barayin, when the Hortative suffix is used on its own, as in examples 16 and 17, the understood subject is first-person dual inclusive, not plural. In order to express first-person plural inclusive hortative meaning in Barayin, the plural addressee marker $n a ̀$ follows the Hortative verb. The enclitic $n a ̀$ is identical to the form used to distinguish the plural imperative construction from the singular imperative construction.

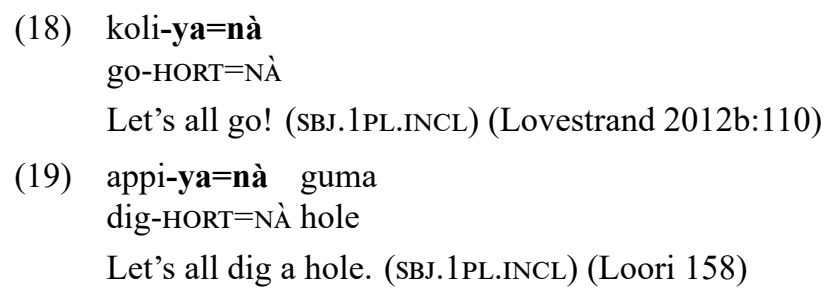

A similar pattern occurs in five other Chadic languages of the Guera. The same post-verbal morpheme that distinguishes plural imperative from singular imperative, also distinguishes the plural hortative construction from the dual hortative construction. One difference is that in these five languages, the marker that appears in the plural forms occurs before the Hortative suffix, where in Barayin it occurs after the Hortative suffix. This is illustrated in the following examples.

(20) Bidiya (Hassane et al. n.d.)

a. dor

listen

Listen! (SBJ.2SG)

b. dor-on

listen-ON

Listen! (SBJ.2PL)

c. dor-ten

listen-HORT

Let's listen! (SBJ.1DU.INCL)

d. dor-on-ten

listen-ON-HORT

Let's listen! (SBJ.1PL.INCL)

(21) Saba (Abakar and Abbazene n.d.)

a. taa

eat

Eat! (SBJ.2sG)

b. tee-n

eat-N

Eat! (SBJ.2PL)

c. taa-yew

eat-HORT

Let's eat! (SBJ.1DU.INCL) 
d. tee-n-ew

eat-N-HORT

Let's all eat! (SBJ.1PL.INCL)

(22) Dangla (Shay 1999)

a. as-u

come-SBJV

Come! (SBJ.2sG)

b. as-on

come-ON

Come! (SBJ.2PL)

c. as-te

come-HORT

Let's come! (SBJ.1DU.INCL)

d. as-on-te

come-ON-HORT

Let's all come! (SBJ.1PL.INCL)

(23) Mogum (Moussa et al. n.d.)

a. waar

dance

Dance! (SBJ.2SG)

b. waar-oy

dance-ON

Dance! (SBJ.2PL)

c. waar-ten

dance-HORT

Let's dance! (SBJ.1DU.INCL)

d. waar-on-ten

dance-ON-HORT

Let's all dance! (SBJ.1PL.INCL)

(24) Sokoro (Yaranga et al. n.d.)

a. bok speak

Speak! (SBJ.2sG)

b. bok-in speak-ON

Speak! (SBJ.2PL)

c. bok-iya

speak-HORT.1DU.INCL

Let's speak! (SBJ.1DU.INCL)

d. bok-in-da

speak-ON-HORT.1PL.INCL

Let's all speak! (SBJ.1PL.INCL) 
A different pattern is found in Migaama. The plural imperative form in Migaama uses the suffix -on which is the same as the morpheme used in both hortative and imperative plural constructions in Bidiya, Dangla and Mogum. However, in Migaama, this suffix is limited to imperative use. It does not appear in the hortative construction. In Migaama there are two Hortative suffixes: - $e \eta$ which has a dual subject and -ne which has a plural subject. The plural Hortative suffix does not appear to be a composite form. It may be the case that Migaama previously had a similar system to the other four languages, which has changed phonologically, and neutralized the evidence for the older pattern.

In summary, in addition to a Subjunctive form, Barayin and at least six other languages also have a Hortative suffix dedicated to first-person (dual and plural) directive meaning. In six of these seven languages, the same plural addressee marker that distinguishes the plural imperative from the singular imperative construction also distinguishes the plural Hortative from the dual.

\subsection{Barayin pronominal paradigms}

Chadic languages most commonly have a personal pronoun system of nine categories including an inclusiveexclusive distinction in the first-person plural (1PL.INCL and 1PL.EXCL) and distinct forms for masculine and feminine in the second- and third-person singular (Newman 2006:196). This is also true of the languages of the Guera subbranch. Of the thirteen languages for which data are available, eight have a 9-pronoun system. Two have a system of only eight personal pronouns with no inclusive-exclusive distinction: Mogum and Kajakse. ${ }^{4}$ The remaining three have a personal pronoun system of ten categories including a first-person dual inclusive (1DU.INCL) pronoun: Barayin, Migaama and Zerenkel (Lovestrand 2012a:28). Outside of the Chadic languages of the Guera, other Chadic languages with a first-person dual inclusive pronoun include the East Chadic language Lele (Frajzyngier 2001:100), the Central Chadic languages Buwal, Gavar (Viljoen 2013:214), Mina (Frajzyngier et al. 2005:81), Mofu-Gudur (Barreteau 1988) and Merey (Gravina 2007) and the West Chadic language Margi (Hoffman 1963:72). Not all of these languages have a masculine-feminine gender distinction so their pronominal paradigms are not identical to those of the Guera Chadic languages. These three types of pronominal paradigms are illustrated in table 1.

Table 1: Three pronominal paradigms in East Chadic B

\begin{tabular}{|c|c|c|c|c|c|}
\hline \multicolumn{2}{|c|}{ 8-pronoun system } & \multirow{2}{*}{\multicolumn{2}{|c|}{ 9-pronoun system }} & \multicolumn{2}{|c|}{ 10-pronoun system } \\
\hline & & & & & 1DU.INCL \\
\hline & & & & & 1PL.INCL \\
\hline $1 \mathrm{SG}$ & 1PL & $1 \mathrm{SG}$ & 1PL.EXCL & $1 \mathrm{SG}$ & 1PL.EXCL \\
\hline $2 \mathrm{SG}(\mathrm{M} / \mathrm{F})$ & $2 \mathrm{PL}$ & $2 \mathrm{SG}(\mathrm{M} / \mathrm{F})$ & $2 \mathrm{PL}$ & $2 \mathrm{SG}(\mathrm{M} / \mathrm{F})$ & $2 \mathrm{PL}$ \\
\hline $3 \mathrm{SG}(\mathrm{M} / \mathrm{F})$ & 3PL & $3 \mathrm{SG}(\mathrm{M} / \mathrm{F})$ & 3PL & $3 \mathrm{SG}(\mathrm{M} / \mathrm{F})$ & 3PL \\
\hline
\end{tabular}

Chadic languages often have several distinct pronominal paradigms for different grammatical functions. The 10-pronoun paradigm is shown for Independent pronouns in Barayin in table 2. In Barayin, in addition to Independent pronouns, separate paradigms exist for pre-verbal Subject pronouns, Direct Object pronominal suffixes, dative (Indirect Object) pronominal suffixes, and nominal Possessive suffixes. In all of these paradigms, the 1DU.INCL is always distinguished from the 1PL.INCL by the morpheme nà in the plural form, as seen in table 3. Each of the first-person plural inclusive forms is composed of the first-person dual inclusive form plus the same plural addressee marker nà that distinguishes plural and non-plural directive forms.

The 1PL.INCL pronominal forms in table 3 are presented with a clitic mark dividing the morpheme $n a ̀$ from the rest of the word. In most cases, the morpheme nà is never separated from the preceding

\footnotetext{
${ }^{4}$ Lovestrand (2012a) erroneously stated that Bidiya has an 8-pronoun system. Some personal pronoun paradigms in the Guera languages are restricted to an 8-way distinction, and others make a 9-way distinction (Alio and Jungraithmayr 1989:34).
} 
Table 2: Independent pronouns in Barayin (Lovestrand 2012b:130)

\begin{tabular}{|c|c|c|c|}
\hline & Singular & Dual & Plural \\
\hline \multirow[t]{2}{*}{1} & \multirow{2}{*}{ inu } & \multirow{2}{*}{ aya (INCL) } & aya=nà (INCL) \\
\hline & & & ane (EXCL) \\
\hline \multirow[t]{2}{*}{2} & killa (M) & & \multirow[b]{2}{*}{ nílla } \\
\hline & kella (F) & & \\
\hline \multirow[t]{2}{*}{3} & kalla (M) & & \multirow[b]{2}{*}{ nilla } \\
\hline & tilla (F) & & \\
\hline
\end{tabular}

Table 3: First-person dual and plural pronouns in Barayin

$\begin{array}{lll} & \text { 1DU.INCL } & \text { 1PL.INCL } \\ \text { Independent } & \text { aya } & \text { aya }=\text { nà } \\ \text { Subject } & \text { in } & \text { in } \ldots=\text { nà } \\ \text { Direct Object } & \text {-ya } & \text {-ya }=\text { nà } \\ \text { Indirect Object } & \text {-aya } & \text {-aya }=\text { nà } \\ \text { Possessive } & \text {-jiya } & \text {-jiya }=\text { nà }\end{array}$

pronoun. For that reason, it might be argued that not all of the 1PL.INCL forms are necessarily bimorphemic. However, a bimorphemic analysis is required for the 1PL.INCL pronoun in the Subject paradigm. Subject pronouns are proclitics occurring before the verb and any preverbal particles. When the subject is firstperson plural inclusive, a form identical to the 1DU.INCL Subject pronoun (written as i $\eta$ but pronounced as a syllabic nasal with high tone $/ \hat{y} /$ ) occurs before the verb, and the plural addressee marker nà occurs after the verb, as seen in examples $25 \mathrm{~b}$ and $26 \mathrm{~b}$. This is contrasted with examples $25 \mathrm{a}$ and $26 \mathrm{a}$ where the preverbal Subject pronoun iy without the postverbal enclitic nà has a first-person dual inclusive meaning. The context of example 25a is that of explaining how marriages used to be conducted. This sentence is reported speech conveying what a groom would say to his new wife, using the dual form. In the context of example $25 \mathrm{~b}$, one friend is proposing a joint activity to a group of friends, using the plural form. Examples $26 \mathrm{a}$ and $26 \mathrm{~b}$ are an elicited minimal pair showing the same contrast.

$$
\text { a. in kol-u alli } \mathrm{g} \text { ana pulan }
$$

SBJ.1DU.INCL go-SBJV there OBL for mister

Let's go (you and me) to that man's house. (bva024.47)

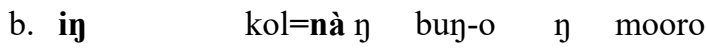

SBJ.1DU.INCL go=NÀ OBL Swim-INF OBL river

Let's all go swim in river! (Loori 231)

$$
\begin{aligned}
& \text { a. in d-eyi d-ii } \\
& \text { SBJ.1DU.INCL walk-IPFV walk-INF } \\
& \text { The two of us walk. } \\
& \text { b. in d-eyi=nà d-ii } \quad \text { SBJ.1DU.INCL walk-IPFV=NÀ walk-INF } \\
& \text { We all walk. (Lovestrand 2012b:133) }
\end{aligned}
$$

Some of the evidence for analyzing nà as a clitic, not a suffix, is that nà can occur after another enclitic, the post-verbal particle $j e$. The precise function of $j e$ is unknown, but its distribution is clear. It is an enclitic occurring directly after the verb, but never between a verb root and its suffixes. In most cases, it follows the morpheme nà, as in example 27, but it can also occur before $n a ̀$, as in example 28 . 
(27) in

wayi-do $=$ nà $=$ je

teyi

SBJ.1DU.INCL spend.the.day-OBL $=\mathrm{NÀ}=$ PART like.this

We spent the whole day like this... (bva040.27)

(28) in $\quad$ sul-do $=\mathbf{j e}=$ nà

SBJ.1DU.INCL sit-OBL $=$ PART $=$ NÀ

We stayed here. (bva154.19)

Dual number in Barayin (as well as other Chadic languages) is limited to first-person. There are no second-person or third-person dual forms. Pronominal systems that limit the use of dual number to firstperson personal pronouns are widespread. According to Cysouw (2001), “...it seems to have neither a clear areal nor a clear genetic distribution." This system is found in Chadic languages, various families of Niger-Congo languages, Austronesian languages of the Philippines, some Californian languages, some Australian languages, and some Papuan languages (Cysouw 2003:139-140). This type of system is also found in at least one Nilo-Saharan language spoken in the Guera region, Daju dar Daju (Aviles 2008:36).

Corbett (2000:166) and Cysouw (2003:87-89) review the literature on the unique status of the firstperson dual pronoun in (primarily Austronesian) languages with a 10-pronoun system like Barayin. One hypothesis that has been repeated several times is that the asymmetry of the dual form can be done away with by reframing the pronominal categories. The terms "singular" and "plural" are replaced with "minimal" (singular and dual) and "augmented" (plural). This analysis is illustrated for Barayin Independent pronouns in table 4, but it will not be adopted in this paper. Cysouw (2003:263) points out a convincing reason for rejecting the minimal/augmented analysis for languages with this type of pronoun paradigm: 'If there were a set of 'minimal' and a set of 'augmented' morphemes, one would expect at least some of these paradigms to show a regular morphological derivation of the augmented set. ... However, this is extremely rare, if it exists at all." In Barayin, there are no morphological patterns distinguishing other minimal/augmented pairs (besides 1DU.INCL and 1PL.INCL) in the pronominal paradigms. In other words, there is no equivalent to the morpheme nà in other "augmented" pronouns. There are also no minimal/augmented agreement forms. The relevant features for number agreement in Barayin are singular and plural (including dual), not minimal and augmented. For these reasons, the minimal/augmented analysis is rejected for Barayin.

Table 4: Minimal/augmented analysis of independent pronouns in Barayin (rejected)

\begin{tabular}{|l|l|l|}
\cline { 2 - 3 } \multicolumn{1}{c|}{} & Minimal & Augmented \\
\hline 1EXCL & inu (SG) & ane (PL) \\
\hline 1INCL & aya (DU) & aya=nà (PL) \\
\hline \multirow{2}{*}{2} & killa (SG.M) & \multirow{2}{*}{ nìlla (PL) } \\
\cline { 2 - 2 } & kella (SG.F) & \\
\hline \multirow{2}{*}{3} & kalla (SG.M) & \multirow{2}{*}{ nílla (PL) } \\
\cline { 2 - 3 } & tilla (SG.F) & \\
\hline
\end{tabular}

In summary, in Barayin the same plural addressee marker nà seen in the directive forms also distinguishes first-person dual inclusive pronouns from first-person plural inclusive pronouns. Before moving on to diachronic analysis, the remainder of this section will look at the use of the plural addressee marker in non-directive contexts in other languages.

In Bidiya, pre-verbal subject markers are normally not accompanied by any verbal inflection. However, in at least some TAM forms, the plural addressee suffix -oy can co-occur with a pre-verbal secondperson plural subject. This suffix does not occur with first-person or third-person plural subjects. It only occurs with second-person plural pre-verbal subjects. This is illustrated by the paradigm in table 5 . 
Table 5: Bidiya pit 'open' with pre-verbal subject pronouns (Alio 1986:195)

\begin{tabular}{|l|l|l|}
\cline { 2 - 3 } \multicolumn{1}{c|}{} & SG & PL \\
\hline 1 & no pit & ni pit \\
\hline $2 \mathrm{M}$ & ki pit & \multirow{2}{*}{ ku pit-on } \\
\hline $2 \mathrm{~F}$ & ka pit & \\
\hline $3 \mathrm{M}$ & ya pit & \multirow{2}{*}{ yu pit } \\
\hline $3 \mathrm{~F}$ & na pit & \\
\hline
\end{tabular}

Verbs in Saba normally do not inflect for subject agreement, but in certain TAM forms, a first-person or second-person subject co-occurs with a plural addressee suffix on the verb, preceding the TAM marking on the verb. This is illustrated in table 6 . The plural addressee marker is redundant in these contexts, since all the number distinctions are found in the Subject pronoun. The distribution of this suffix in Saba challenges an analysis of the suffix as a marker of "plural addressee" since it is also used with an exclusive subject. It seems that the meaning of the marker in Saba expanded to include all first-person and second-person plural forms.

Table 6: Saba teelin 'quarrel' with subject pronouns (Abakar and Abbazene n.d.)

\begin{tabular}{|l|l|l|}
\cline { 2 - 3 } \multicolumn{1}{c|}{} & SG & PL \\
\hline \multirow{2}{*}{1} & no teelin-e & kew teelin-n-e (INCL) \\
& & ken teelin-n-e (EXCL) \\
\hline 2M & ki teelin-e & \multirow{2}{*}{ kun teelin-n-e } \\
\hline 2F & kay teelin-e & \\
\hline $3 \mathrm{M}$ & a teelin-e & \multirow{2}{*}{ án teelin-e } \\
\hline $3 \mathrm{~F}$ & ay teelin-e & \\
\hline
\end{tabular}

In summary, Saba has the widest distribution of non-directive use of the plural addressee suffix. At least in some TAM, it can co-occur with three types of subjects: second-person plural, first-person plural inclusive, or first-person plural exclusive. In Barayin, the enclitic nà must always occur in order to express any first-person plural inclusive meaning (in all TAM forms). It can also occur with a second-person plural subject, but only in the Subjunctive TAM. In Bidiya, the suffix -oy only occurs with second-person plural subjects outside of the hortative/imperative constructions. In Sokoro, Mogum and Dangla, it appears that the plural addressee marker is restricted to hortative and imperative forms. These differences are summarized in table 7.

Table 7: Subjects accompanied by a plural addressee marker outside of hortative/imperative

\begin{tabular}{|r|c|c|c|}
\cline { 2 - 4 } \multicolumn{1}{c|}{} & 2PL & 1PL.INCL & 1PL.EXCL \\
\hline Saba & $\mathrm{X}$ & $\mathrm{X}$ & $\mathrm{X}$ \\
\hline Barayin & $\mathrm{X}$ & $\mathrm{X}$ & \\
\hline Bidiya & $\mathrm{X}$ & & \\
\hline Mogum & & & \\
\hline Dangla & & & \\
\hline Sokoro & & & \\
\hline
\end{tabular}

Since there are several morphemes in Barayin that have a similar phonological shape to the plural addressee marker $n a ̀$, the source of the marker cannot be determined by looking at Barayin alone. However, looking at all the Chadic languages of the Guera that have a plural addressee marker, the most consistent 
pattern is a phonological similarity between the plural addressee marker and the second-person plural pronominals. These plural addressee markers are listed in the second column of table 8 alongside the second-person plural pronominal forms. In most languages, the plural addressee marker is -oy, and the second-person plural pronouns are similar to koy. The plural addressee marker can be derived by deleting the initial consonant.

Table 8: Second-person plural pronominals in five languages

\begin{tabular}{|c|c|c|c|c|}
\hline & Plural Adr. & Subject & Direct Object & Indirect Object \\
\hline Barayin & $=$ nà & ní & $-\eta ́$ & -ay \\
\hline Bidiya & -oy & kun / -kun & -kuy & -kun \\
\hline Dangla & -on & ku / -kon & -kon & -kon \\
\hline Mogum & -oy & ku / kun & -gon & -kon \\
\hline Saba & $-n /-y$ & kun & -gun / -gune & -tuy / -tigun \\
\hline Sokoro & -in & kuy & -gun & -un \\
\hline
\end{tabular}

In the following section, we turn from the synchronic description to a diachronic analysis. Section 3 explains the grammaticalization of the first-person dual pronoun in Barayin. Section 4 discusses the grammaticalization path of the Hortative suffix in Barayin and related languages.

\section{From first-person plural to first-person dual}

This section explains the path of grammaticalization that created a form with first-person dual number in Barayin. In this path of grammaticalization, a first-person dual inclusive pronoun is derived from a first-person plural inclusive pronoun. This is a path of grammaticalization previously attested in other languages around the world. Particularly convincing evidence for this analysis in Barayin comes from comparing dialects.

As described in section 2.2, Barayin has a 10-pronoun system. This system has a first-person dual inclusive pronoun, but no other dual pronouns. There is a generally accepted path of grammaticalization for first-person dual pronouns in this type of pronominal system: "The form of the dual pronoun, especially in many Philippine languages... suggests that the dual pronoun was originally a first-person inclusive pronoun, the reference of which has been restricted to a single first-person and a single second-person. In these languages, the form of the first-person inclusive pronoun typically has an additional formative..." (Reid 2009). The most likely explanation for this restriction in meaning from plural to dual is that "most conversations take place between a speaker and a single hearer. As a result, the use of an inclusive pronoun would normally involve only the conversational dyad of speaker and hearer" (Blust 2013:320).

The Barayin pronominal system confirms this analysis. The 1DU.INCL pronouns, such as the independent pronoun aya, are identical to the 1PL.INCL pronouns, such as aya=nà, except for an additional morpheme nà in the plural form. The path of grammaticalization for Barayin is modeled in figure 1. The fact that the two parts of the 1PL.INCL Subject pronoun are separated by a verb makes the historically bimorphemic nature of the plural pronoun all the more obvious (example 26b). As Greenberg (1988:6) notes, "the composite nature of the new first inclusive plural is shown vividly in a few languages in which the new form of the first inclusive plural has discontinuous constituents."

Even more evidence for this shift is provided by the fact that one dialect of Barayin (Jalking) has no 1DU.INCL independent pronoun. Its monomorphemic 1PL.INCL independent pronoun aye is very similar to the 1DU.INCL pronoun in the other Barayin dialects (table 9). Therefore, we can surmise that the 1PL.INCL pronoun in Jalking is representative of an older pronominal system. That older form became the 1DU.INCL in the other three dialects of Barayin, but has remained plural in Jalking. The three dialects that restricted 
Figure 1: Illustration of grammaticalization of first-person dual pronoun in Barayin

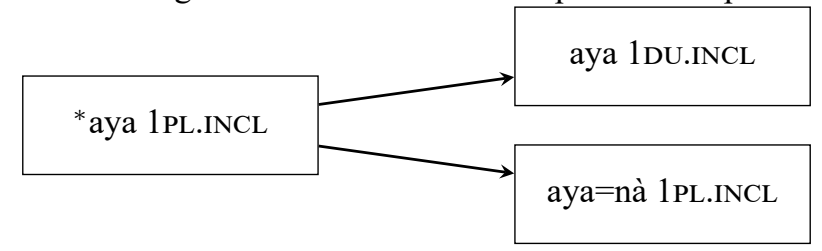

the meaning of aya to 1DU.INCL can now only express the 1PL.INCL by combining the morpheme nà to what became the 1DU.INCL form.

Table 9: First-person independent pronouns in four Barayin dialects

\begin{tabular}{|l|l|l|l|l|}
\cline { 2 - 5 } \multicolumn{1}{c|}{} & Komiya & Jalking & Giliya & Jalkiya \\
\hline 1SG & unu & unu & inu & inu \\
\hline 1DU.INCL & aya & - & aya & aya \\
\hline 1PL.INCL & ayana & aye & ayana & ayana \\
\hline 1PL.EXCL & ane & ane & ane & ane \\
\hline
\end{tabular}

Within the Chadic languages of the Guera (East Chadic B), at least two other languages have a firstperson dual pronoun: Migaama and Zerenkel. In Migaama, the first-person dual Subject pronoun is also a discontinuous form, but so is the first-person dual inclusive. This can be seen in table 10. In the Subject form, the morpheme before the verb is identical whether the subject is 1DU.INCL or 1PL.INCL, just like in Barayin. However, in Migaama, both dual and plural subjects are accompanied by an obligatory postverbal morpheme. In non-Subject paradigms, there is no sign that either pronoun is bimorphemic. It is also possible for a post-verbal plural addressee marker (used in the plural imperative, but not in the plural hortative) to accompany second-person plural subjects, but this is not accepted by all Migaama speakers (Sakine Ramat, personal communication).

Table 10: Some dual and plural pronouns in Migaama (Jungraithmayr and Adams 1992)

\begin{tabular}{|l|l|l|l|l|l|}
\cline { 2 - 6 } \multicolumn{1}{c|}{} & 1DU.INCL & 1PL.INCL & 1PL.EXCL & 2PL & 3PL \\
\hline Independent & kéntà / kén & kéètà / kéè & níità / níì & kûntà / kûy & gùtà \\
\hline Subject & ké ... -(y)èn & ké ... -(i)nè & ní & kú ... -(y)òy & gù \\
\hline Direct Object & -én & -né & -ní & -tóy & -ì \\
\hline
\end{tabular}

The pronominal system of Zerenekel does not use any discontinuous or bimorphemic forms. The firstperson independent pronouns are shown in table 11. The first-person dual and plural inclusive pronouns are distinct forms: aya and ana. The Subject pronouns are similar forms: ay and an. It is possible that Zerenkel may have undergone phonological changes that completely mask the grammaticalization process, but even this is unlikely. The most closely related language to Zerenkel is Mubi. The first-person plural pronouns in Mubi are nearly identical to Zerenkel, as seen in table 11. If the first-person dual pronoun in Mubi had developed in the same way as Barayin, it would be expected to have a similar form to the first-person plural inclusive in Mubi, and the first-person plural inclusive in Zerenkel would be expected to have the same form as the first-person plural inclusive in Mubi plus some other morpheme added to it. Perhaps Mubi had a dual pronoun that was lost, but it seems more likely that Zerenkel developed their dual pronoun in a different way, although it is not yet clear what happened. 
Table 11: first-person dual and plural pronouns in Mubi and Zerenkel

\begin{tabular}{|l|l|l|}
\cline { 2 - 3 } \multicolumn{1}{c|}{} & Zerenkel & Mubi \\
\hline 1DU.INCL & aya & - \\
\hline 1PL.INCL & ana & ana \\
\hline 1PL.EXCL & ini & ene \\
\hline
\end{tabular}

\section{From dative to hortative}

Wolff (1982b) points out that the Hortative suffix in Dangla is identical to the first-person plural dative (Indirect Object) suffix. It turns out that the same is true in at least six other related languages, although in the case of Barayin and Sokoro there is a slight difference in phonological form. The hortative and dative suffixes are shown in table 12. Since all seven instances of a Hortative suffix share this relationship to a dative suffix, it is clear that the pattern is indicative of a historical link, and not a coincidence. This conclusion is supported by the fact that the suffixes are not similar cross-linguistically. In other words, it is not the case that Hortative suffixes and dative suffixes in this subbranch just happen to all be similar to each other.

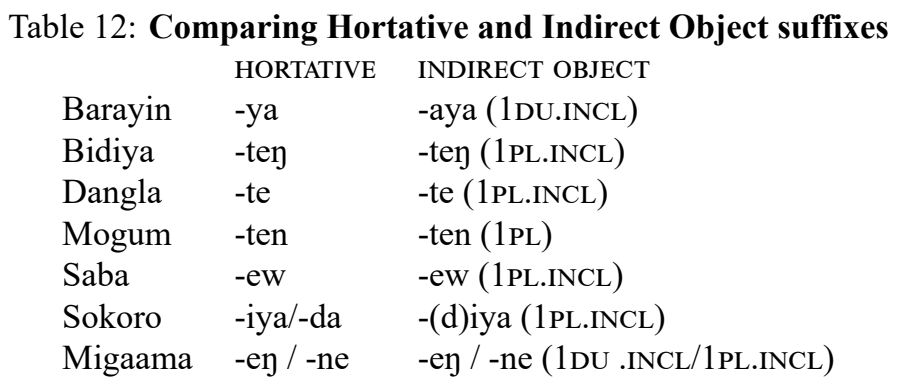

There does not appear to be any discussion in the literature of a dative pronominal marker as the most likely diachronic source of a hortative marker. This source is not included in a survey of diachronic sources of hortative forms (Mauri and Sansò 2011), or in a list of grammaticalizations originating in dative markers (Heine and Kuteva 2002). These data are a first chance to explore this path of grammaticalization.

In terms of morphological structure, it is not surprising that one verbal suffix would be reanalyzed as another category of verbal suffix since they essentially occupy the same position in the verbal morphology. It is less clear how the anaphoric function of a dative suffix became reinterpreted as directive (hortative) meaning. The most likely explanation for grammaticalization is that the use of the first-person dative pronoun in a personal dative construction is semantically and structurally analogous to Subjunctive forms. This grammaticalization path correlates with the presence of a plural addressee marker used in both imperative and hortative constructions. It results in a first-person dual form even when the language has no dual pronouns. It appears that the plural addressee marker somehow facilitated grammaticalization of the personal dative construction, which is otherwise not expected to grammaticalize into a hortative marker.

Before further explaining the motivation for this grammaticalization, the following sets of examples demonstrate the synchronic functions of the dative suffix. Examples 29 and 30 illustrate, in Barayin, subcategorized uses of the dative with the ditransitive verbs "give" or "say". The dative suffix indexes the recipient or addressee marked by an Oblique preposition.
(29) $\mathrm{ki}$
bed-ati $=$ ga
y átt-eti
y i-go

SBJ.2SG.M give-DAT.3SG.F=OBJ.3SG.M OBL hand-POSS.3SG.F OBL mother-POSS.2sG.m 
You give it to your mother. (bva025.13)

(30) $y \quad$ gas-aga $y$ mejer-a-tu

SBJ.1SG Say-DAT.3PL OBL people-PL-POSS.1SG

I tell my relatives. (bva026.24)

With verbs that express a change of location of their theme/patient, the dative suffix can reference the destination or goal of the movement.

(31) atibe joo s-aa pepir-aw

ashes FOC come-SBJV sprink-DAT.1SG

Come sprinkle the ashes on me. (Jebile 91)

With verbs that do not have the semantics of a recipient or goal, the dative suffix can reference some other argument effected by the event or state of affairs. That argument can also be marked by an Oblique preposition as in example 32. The use of a dative suffix to index a beneficiary argument in examples 32 , 33 and 34 is a case of what Horn (2008:184) calls "non-subcategorized datives".

(32) wool-ati-ti=nà $\quad$ y Asiye

slaughter-DAT.3sG.F=OBJ.3sG.F=NÀ OBL Asiye

Slaughter it for Asiye! (bva086.52)

(33) duwa kol-eyi deg-aga suu

lion go-IPFV kill-DAT.3PL animal

The lion went out killed an animal for them. (Carnivores 11)

(34) hoy ep-aw=ti

hey catch-DAT. $1 \mathrm{sG}=$ OBJ.3sG.F

Hey! Catch her for me! (Bulmi 50)

In Barayin, a non-subcategorized dative can also have a malefactive interpretation.

(35) nopuno-ya sile wod-aya=nà
goat-PL PROG destroy-DAT.

wod-o

goat-PL PROG destroy-DAT.1DU.INCL=NÀ destroy-INF

The goats are destroying (our fields). (bva039.12)

(36) ke ganda t-eg-aw=ni liya-tu

SBJ.2SG.F PROG eat-IPFV-DAT.1SG=OBJ.3PL things-POSS.1sG

You are eating my stuff! (Bulmi 57)

Some types of unsubcategorized datives, such as "ethical datives" found in Greek, Latin, Romance languages and German, are interpreted as referring to a beneficiary or malefactive participant that is not co-referential with any of the participants subcategorized for by the predicate. Horn (2008) points out that these ethical datives are distinct from another construction that he calls "personal datives". The primary distinction is that, in personal dative constructions, the dative is co-referential with the subject, as in the following examples from Horn (2008).

(37) a. I'm gonna buy me a shotgun, just as long as I am tall (Jimmie Rodgers, "T for Texas")

b. Can I get me a hunting license here? (John Kerry)

c. I just love me some Jude Law.

d. I love me some me. (Terrell Owens) 
Personal datives communicate a "typically benefactive subject affect" (Horn 2008:188). In other words, a personal dative construction is designed to express the fact that the subject is doing something for their own benefit. This meaning is relatively close to the pragmatic implication of hortative meaning where the performers, both speaker and adressee(s), are directed to do something which is presumably for their own benefit. Horn (2008:178) points out that in descriptions of personal dative constructions around the world, there is a strong preference for first-person.

Part of the explanation for how a hortative suffix was grammaticalized from a dative suffix in these Chadic languages is to posit a hypothetical stage of the language where the dative suffix was used to create a type of personal dative construction. In this personal dative construction a first-person dative suffix is co-referential with the subject of the verb. The best evidence for this initial stage is an example from Barayin where the speaker uses a subject pronoun with a Hortative form. The subject pronoun is first-person dual inclusive.

$$
\begin{aligned}
& \text { s-aa japp-a-ge in dowi-ya dow-o } \\
& \text { come-SBJV want-IPFV-OBJ.2SG.F SBJ.1DU.INCL go.to.bed-HORT go.to.bed-INF }
\end{aligned}
$$

Come here! I want you. Let's sleep together. (bva052.100)

The hypothetical personal dative construction is very similar in meaning to hortative in that both involve a self-benefiting motivation for the state of affairs described by the verb. Like directive forms, the personal dative also implies "an appeal to the addressee(s) [first-person subject] to help make this SoA true" (Mauri and Sansò 2011:3491). The functional overlap between a personal dative construction and the Subjunctive form creates the context in which the dative suffix can be reinterpreted as a TAM suffix on analogy with the Subjunctive suffix.

Table 13 illustrates the structural similarity between the dative suffix and the Subjunctive suffix that facilitated the reanalysis of the pronominal suffix as a TAM suffix. The first column is the hypothetical personal dative construction. Subjects in Barayin can be omitted whenever the subject is clear from context, as would be the case in a personal dative construction. When a dative suffix is used in Barayin, it normally suppletes the TAM marking such that the dative suffix is the only verbal suffix. The third column in table 13 shows the imperative use of the Subjunctive in which the subject is obligatorily absent, and the suffix on the verb is a TAM suffix encoding a type of directive meaning. The subjectless personal dative construction likewise appears to be a directive construction in which a single suffix is attached to the verb. It is plausible that this single suffix in the context of directive meaning was reanalyzed as a TAM suffix instead of a pronominal suffix. The second column is the reanalysis in which the suffix is no longer considered a pronominal suffix, but a TAM suffix on analogy with the imperative use of the Subjunctive suffix. The hypothesis that the reanalysis took place on analogy with the imperative use of the Subjunctive is strongly supported by the use of plural addressee marker (nà in Barayin) in the plural forms of both the imperative and hortative constructions (section 2.1).

Table 13: Reanalysis on analogy with imperative

\begin{tabular}{|l|l|l|}
\hline $\begin{array}{l}\text { from } \\
\text { personal dative (hypothetical) }\end{array}$ & $\begin{array}{l}\text { to } \\
\text { hortative }\end{array}$ & $\begin{array}{l}\text { on analogy with } \\
\text { imperative }\end{array}$ \\
\hline (Pronoun) V-Pronominal & V-TAM & V-TAM \\
\hline (in) kol-aya(=nà) & kol-ya(=nà) & kol-u(=nà) \\
\hline (SBJ.1DU.INCL) go-DAT.1DU.INCL & go-HORT & go-SBJV \\
\hline [We] go for us. & Let's go! & Go! \\
\hline
\end{tabular}

As stated in section 2.1, in most of the languages where a hortative suffix grammaticalized from a dative suffix, the hortative suffix has dual number when used on its own, and plural number when combined with a plural addressee marker. This is true even in the five languages where the formally 
identical dative suffix has plural number. In fact, these five languages have no dual number anywhere outside of the hortative construction. One way to account for the change from plural to dual is to assume that the process was the same as that seen in the grammaticalization of a first-person dual pronoun in Barayin (section 3). This would imply a process where the first-person plural dative suffix became a plural hortative suffix, and then further grammaticalized into dual hortative suffix only retaining its plural meaning in combination with a plural addressee marker.

Alternatively, the dual number in the hortative form could be analyzed as originating in what Corbett (2000:169) calls “constructed number" (see also Arka 2011; Nordlinger 2012; Sadler 2010). Constructed number is when a grammatical number value does not correlate with a single lexeme, but can be constructed in the language by a combination of other grammatical morphemes. Constructed number in Hopi (Uto-Aztecan) works synchronically in a way that could explain how dual number was derived diachronically in Barayin. Verbs in Hopi inflect for singular or plural subject agreement. Unsurprisingly, when a singular subject pronoun is used with a singular verb form, the number of the subject is singular (example 39a). In the same way, when a plural subject pronoun is used with a plural verb form, the number of the subject is plural (example 39b). The more interesting case is when a singular subject pronoun combines with a plural verb form (example 39c). In this case, the number of the subject is dual. The dual subject number is constructed from a singular pronominal form and a plural verbal form.

(39) Hopi (Uto-Aztecan) (Corbett 2000:169; Hale 1997:74)

a. pam wari

DEM.SG run.PFV.SG

$\mathrm{He} / \mathrm{she}$ ran.

b. puma yùutu

DEM.PL run.PFV.PL

They ran.

c. puma wari

DEM.PL run.PFV.SG

They (two) ran.

Returning to the grammaticalization of hortative forms in Chadic languages, note that the verb root form in the hortative constructions are all formally identical to the singular imperative root form. It is possible that the dual subject number in this context was constructed from a form of the verb signaling a singular subject, and a suffix signaling a plural subject.

Personal dative constructions are relatively common among the languages of the world, but the grammaticalization of a dative marker to a hortative marker is not common. The secondary element that appears to be key to this grammaticalization process is the presence of plural addressee marker. Almost all of the languages in the Guera subbranch that have grammaticalized a hortative marker from a dative marker also have a plural addressee marker which is used in the hortative construction. The exception is Migaama. Migaama has what looks like a plural addressee marker -oy in the plural imperative form, but this marker is not used in the hortative forms. Instead there two different monomorphemic Hortative suffixes, one for dual and one for plural. It may be the case that Migaama hortatives previously looked like Barayin, but the plural addressee marker and the hortative marker merged into one morpheme.

The same path of grammaticalization appears to have occurred elsewhere. One parallel is found in another East Chadic language, Lele, spoken in the Logone-Chari area in the southern part of Chad (East Chadic A). Subject pronouns are described as having a discontinous form, like in Barayin: "The firstperson plural inclusive is a special construction consisting of the first-person dual inclusive preceding the verb and the second-person plural following the verb" (Frajzyngier 2001:100). A similar observation is made about object pronouns: "The first-person plural inclusive is formed through the combination of the 
first-person dual inclusive and the-second-person plural: $\eta g a-\eta g u$ " (Frajzyngier 2001:109). Similar forms are found in dual and plural hortative forms.

The Central Chadic language Lamang uses a prefix wà- for plural imperatives (Wolff 1983:175-177). It also has a dual hortative form with a prefix $m \grave{a}-$, and a plural hortative form which combines both prefixes $m \grave{a}-w \grave{a}-$. In other words, wà acts as a plural addressee marker for both imperative and hortative plural forms. Like in Barayin, the hortative prefix $m \grave{a}$ - is identical to a dual object suffix, which is combined with wà to create a bi-morphemic plural object suffix.

Further afield, but still in the Afroasiatic phylum, several varieties of Berber show the same pattern as Barayin. As seen in the example 40, in one variety a suffix - $t$ distinguishes the plural imperative from the singular imperative as well as the plural hortative from a dual hortative (Quitout 1997:95). The hortative suffix is identical to the first-person plural dative marker (Quitout 1997:123). In Berber, this is the only dual number in the grammar, just like in several Chadic languages. Identical or similar patterns have been described for other varieties of Berber (Bentolila 1981:75, 140; Boukhris et al. 2008:74, 86; Kossmann 1997:126, 347). ${ }^{5}$

(40) Berber (Quitout 1997:95)

a. sers

put

Put! (SBJ.2sG)

b. sers-t

put-T

Put! (SBJ.2PL.M)

c. sers-ax

put-HORT/1PL.DAT

Let's (you and me) put! (SBJ.1DU)

d. sers-t-ax

put-T-HORT/1PL.DAT

Let's all put! (SBJ.1PL)

\section{Conclusion}

The fact that several related languages have derived a hortative marker from a pronominal suffix is an unusual and intriguing linguistic phenomenon. This may be the first time that a diachronic relationship between a dative marker and hortative marking has been attested. Semantically, it is most likely the benefactive use of the dative that led to this grammaticalization. However, the benefactive use of datives is very common, and the grammaticalization of a dative into a hortative marker is very rare. If this is the semantic motivation, why does this change not happen more often? It appears that this path of grammaticalizaton is facilitated by a plural addressee marker. The dative-derived hortatives occur with a plural addressee marker that distinguishes a plural subject from a dual subject. While the pattern clearly suggests this link, the explanation for this connection remains an open question.

This study also confirms that the path of grammaticalization attested for the development of firstperson dual pronouns in other parts of the world also took place relatively recently in Barayin. The same path of grammaticalization is the most likely explanation for other Chadic languages with similar pronominal systems, even when there is little or no synchronic evidence of the change remaining. However, in the case of Zerenkel this analysis is much less plausible suggesting that there may be more than one way to develop a first-person dual pronoun in a Chadic language.

\footnotetext{
${ }^{5}$ Thanks to Carsten Peust for bringing this to my attention.
} 
In regards to the typology of Chadic languages, the existence of first-person dual pronouns and hortative markers has been noted in individual languages, but this study suggests that both could be more common than previously thought. Data on verbal morphology is only available for thirteen of twenty of the Chadic languages of the Guera. Seven of those have a dedicated first-person Hortative marker-more than half! Note that it is not assumed that all hortative markers in Chadic developed from dative markers. For example, Kanakuru has a first-person plural hortative suffix, but no dual hortative, and the suffix is not similar to any first-person plural pronominal markers (Newman 1974:59). First-person dual pronouns may also be a more frequent Chadic grammatical feature than previously thought, but more research is needed to know how widely they are found.

It is unclear what, if any conclusions can be drawn to further develop the uncertain state of knowledge of classification and genetic relationships of the Chadic languages of the Guera. It is plausible that the existence of a Hortative suffix in seven languages is a sign of a particularly close genetic relationship. However, the fact that Hortative and dative suffixes are similar to each other in each language, but distinct from language to language, suggests that the changes were more recent. If the Hortative form was developed in a proto-language before the forms changed in each language, then it would be surprising that the Hortative suffixes also changed in exactly the same ways as the dative pronouns in each language. It instead appears that the phonological shape of the dative suffixes changed in different directions before the change to Hortative. That seven languages made the same change could either be explained as an areal or contact phenomenon, or as a consequences of some other grammatical feature (like a plural addresee marker) that all these languages share which tends to produce this type of change.

\section{References}

Abakar, A. and Abbazene, Y. (n.d.). Esquisse grammaticale de la langue saba. SIL Chad, unpublished manuscript.

Aikhenvald, A. Y. (2010). Imperatives and commands. Oxford Studies in Typology and Linguistic Theory. Oxford University Press, Oxford.

Alio, K. (1986). Essai de description de la langue bidiya du Guéra (Tchad): Phonologie, grammaire. Dietrich Reimer, Berlin.

Alio, K. and Jungraithmayr, H. (1989). Lexique bidiya. Klostermann, Frankfurt-am-Main.

Arka, W. (2011). Constructive number systems in Marori and beyond. In Butt, M. and King, T. H., editors, Proceedings of the LFG2011 Conference. CSLI Publications.

Aviles, A. J. (2008). The phonology and morphology of the Dar Daju Daju language. MA thesis, University of North Dakota, Grand Forks.

Barreteau, D. (1988). Description du Mofu-Gudur: Livre 1 Phonologie. ORSTOM, Paris.

Bentolila, F. (1981). Grammaire fonctionnelle d'un parler berbère.

Blust, R. (2013). The Austronesian languages. Pacific Linguistics, Canberra.

Boukhris, F., Boumalk, A., El-Moujahid, E.-H., and Souifi, H. (2008). La nouvelle grammaire de l'amazighe. Publications de l'IRCAM, Rabat.

Corbett, G. (2000). Number. Cambridge textbooks in linguistics. Cambridge University Press, Cambridge, UK ; New York. 
Cysouw, M. (2001). Review of A grammar of Lele by Zygmund Frajzyngier (2001). Linguistlist, 12(3099). [url: http://linguistlist.org/issues/12/12-3099.html].

Cysouw, M. (2003). The paradigmatic structure of person marking. Oxford studies in typology and linguistic theory. Oxford University Press, Oxford ; New York.

Frajzyngier, Z. (1996). Grammaticalization of the complex sentence: A case study in Chadic. John Benjamins, Philadelphia.

Frajzyngier, Z. (2001). A Grammar of Lele. CSLI Publications, Stanford, CA.

Frajzyngier, Z. (2002). A grammar of Hdi. Walter de Gruyter, Berlin.

Frajzyngier, Z., Johnston, E., and Edwards, A. C. (2005). A grammar of Mina. Mouton de Gruyter, Berlin; New York.

Gravina, R. (2007). The verb phrase in Merey. SIL Cameroon, Yaounde.

Greenberg, J. (1988). The first person inclusive dual as an ambiguous category. Studies in Language, 12(1):1-18.

Hale, K. (1997). Some observations on the contributions of local languages to linguistic science. Lingua, 100(1):71-89.

Hassane, A., Djamil Baba, A., Nahar, A., and Seibel, S. (n.d.). Esquisse Bidiya DTL 2010, 2012 et 2013: Le nom et le syntagme nominal, Le verbe et le syntagme verbal, Proposition et phrases complexes. SIL Chad, unpublished manuscript.

Heine, B. and Kuteva, T. (2002). World lexicon of grammaticalization. Cambridge University Press.

Hoffman, C. (1963). A grammar of the Margi language. Oxford University Press, London.

Horn, L. R. (2008). "I love me some him": The landscape of non-argument datives. Empirical Issues in Syntax and Semantics, 7:169-192.

Jungraithmayr, H. and Adams, A. (1992). Lexique migama: Migama-français et français-migama (Guéra, Tchad), avec une introduction grammaticale. Dietrich Reimer Verlag, Berlin.

Kossmann, M. G. (1997). Grammaire du parler berbère de Figuig (Maroc oriental), volume 10. Peeters.

Lovestrand, J. (2011). The dialects of Baraïn (East Chadic). SIL Electronic Working Papers, 2011-011.

Lovestrand, J. (2012a). Classification and description of the Chadic languages of the Guéra (East Chadic B). SIL Electronic Working Papers, 2012-004.

Lovestrand, J. (2012b). The linguistic structure of Baraïn (Chadic). Master's thesis, Graduate Institute of Applied Linguistics, Dallas, TX.

Mauri, C. and Sansò, A. (2011). How directive constructions emerge: Grammaticalization, constructionalization, cooptation. Journal of Pragmatics, 43(14):3489-3521.

Moussa, Y., Djerma, H., and Kuipers, E. (n.d.). DTL novembre 2010 : Structures grammaticales en mogoum (revisé octobre 2012). SIL Chad, unpublished manuscript.

Newman, P. (1974). The Kanakuru language. Institute of Modern English Language Studies, University of Leeds, and the West African Linguistic Society, Leeds, Yorkshire. 
Newman, P. (2006). Comparative Chadic revisited. In Newman, P. and Hyman, L., editors, West African linguistics: Papers in honor of Russell G. Schuh, pages 188-202. Ohio State University, Columbus.

Nordlinger, R. (2012). Number marking in the Daly languagues (Australia). In Butt, M. and King, T. H., editors, Proceedings of the LFG12 Conference, pages 422-439. CSLI Publications.

Quitout, M. (1997). Grammaire berbère (rifain, tamazight, chleuh, kabyle). Editions L'Harmattan.

Reid, L. A. (2009). The reconstruction of a dual pronoun to Proto Malayo-Polynesian. In Evans, B., editor, Discovering history through language: papers in honour of Malcolm Ross, pages 461-477. Pacific Linguistics, Canberra.

Sadler, L. (2010). Indeterminacy, complex features and underspecification. Morphology, 21(2):379-417.

Schuh, R. (1998). A grammar of Miya. University of California Press, Berkeley.

Shay, E. (1999). A grammar of East Dangla: The simple sentence. PhD dissertation, University of Colorado, Boulder.

Viljoen, M. (2013). A grammatical description of the Buwal language. PhD dissertation, La Trobe University.

Wolff, E. (1982a). "Aspect" and aspect-related categories in Chadic. In Jungraithmayr, H., editor, Chad languages in the Hamitosemitic-Nigritic border area, pages 183-191. Deitrich Reimer, Berlin.

Wolff, E. (1982b). Review of C. Ebobissé: Die Morphologie des Verbs im Ost-Dangaleat (Guera, Tschad). Berlin, 1979. Journal of African Languages and Linguistics, 4:198-217.

Wolff, E. (1983). A grammar of the Lamang language. Verlag J.J. Augustin, Glückstadt.

Yaranga, A., Yaranga, H., and van Rijn, R. (n.d.). Esquise grammaticale de la langue sokoro du Guéra. SIL Chad, unpublished manuscript. 